\title{
New names for New Zealand weeds
}

\author{
P.D. Champion ${ }^{1}$, T.K. James ${ }^{2}$ and M.I. Dawson ${ }^{3}$ \\ ${ }^{1}$ NIWA, PO Box 11-115, Hamilton 3251, New Zealand \\ ${ }^{2}$ AgResearch, Ruakura Research Centre, P. Bag 3123, Hamilton 3240, New Zealand \\ ${ }^{3}$ Landcare Research, PO Box 40, Lincoln 7640, New Zealand \\ Corresponding author: p.champion@niwa.co.nz
}

\begin{abstract}
There have been numerous changes in botanical names of New Zealand weeds and their assignment to plant families since the publication of the relevant Flora of New Zealand volumes. This paper outlines the reasons behind the changes in nomenclature, including the recent use of DNA sequencing to classify plants by the Angiosperm Phylogeny Group (APG). Currently accepted name changes and new assignment of families for weeds in New Zealand are listed.
\end{abstract}

Keywords angiosperm phylogeny, plant names, taxonomy, weeds, ICBN, APG.

\section{INTRODUCTION}

The standard references for the introduced plants in New Zealand are three volumes of the Flora of New Zealand series. Volume 3 covered all naturalised monocotyledonous plants with the exception of grasses (Healy \& Edgar 1980); Volume 4 covered naturalised pteridophytes, gymnosperms and dicotyledonous plants (Webb et al. 1988) and, most recently, in Volume 5 Edgar \& Connor (2000) have covered grasses, both native and naturalised. Since these volumes were published, taxonomists, both in New Zealand and overseas, have continued to increase knowledge of the world's flora.

This paper presents the currently accepted botanical names of introduced weeds in New Zealand and also notes changes to their plant families where these differ from the Flora treatments. These new names and family arrangements are used in the most recent edition of "An Illustrated Guide to Common Weeds of New Zealand" (Popay et al. 2010). The new names are also followed in the Landcare Research Ngā
Tipu o Aotearoa - New Zealand Plants databases (Landcare Research 2010).

\section{WHAT'S IN A NAME?}

Naming and classification of plants follow the system introduced by Linnaeus (1753) and the development of the International Code of Botanical Nomenclature (ICBN), the latest version being ratified in Vienna in 2006 (ICBN 2006). The guiding principle in botanical nomenclature is priority, i.e. the earliest valid name published for a species takes priority over later names. A botanical name is fixed to a plant by a type specimen. These specimens are usually dried, pressed and the labelled plant material deposited and preserved in herbaria. Any change in taxonomy (e.g. deciding that a group of plants is different from the type specimen and warrants a new specific or subspecific rank name) must also be published and accompanied by its own type specimen. Plant names are accompanied by the name of the taxonomist who first described the 
species. For example, Lagarosiphon major (Ridl.) Moss was first named as a variety of Lagarosiphon muscoides Harv. (var. major Ridl.) by Henry Ridley in the Journal of the Linnaean Society in 1886, then elevated to species rank by Charles Moss in the Transactions of the Royal Society of South Africa in 1928 (International Plant Names Index 2010). The earlier name (Lagarosiphon muscoides var. major) is no longer accepted as a current name and becomes a synonym of L. major.

\section{WHY DO WE HAVE ALL THESE CHANGES?}

Changes to botanical plant names are intended to more accurately reflect the true relationships between plant groups. Although some plant names have remained unchanged since first described by Linnaeus and his contemporaries, others have had extensive changes. The seemingly continuous changes in names are not a new phenomenon (although recent molecular-based taxonomic techniques have led to some major unexpected changes). In the late 1920s renowned New Zealand botanist Leonard Cockayne bemoaned the adherence to the ICBN, meaning that previously well-used botanical names for New Zealand natives such as flax (Phormium Colensoi-back then species named after botanists were afforded a capital letter), pohutukawa (Metrosideros tomentosa) and southern rata (M. lucida) were to be replaced by $P$. tenax, M. excelsa and M. umbellata respectively. Interestingly, Cockayne states in the case of flax, "to change the name for that highly-important economic plant would not be tolerated" (Cockayne 1929). However, the currently accepted names, all earlier published names of the same taxa, are now those used. Similarly insignis pine (Pinus insignis) is now known as radiata pine ( $P$. radiata). It is rather ironic that Cockayne's concerns over a name change were made in the paper that discussed Cockayne and H.H. Allan's transfer of New Zealand Veronica to Hebe (Cockayne 1929). Recent molecular-based evidence suggests they should be transferred back to Veronica, but more of that later.
Since the publication of Floras 3 to 5 there have been several reasons for the name changes to the weeds listed below. In some cases the plants have been incorrectly assigned a species name in New Zealand and are actually a different species (a misapplication), or taxonomic revisions have recognised new species or new ranks (e.g. subspecies or variety). An example is fleabane, now known in New Zealand as Conyza sumatrensis, but previously called C. albida or C. floribunda (all South American species). Genus names have also been changed, e.g. water cresses (Nasturtium spp.) were previously included in the genus Rorippa.

Until relatively recently these changes have been based on plant morphology, usually reproductive morphology (e.g. floral characters) as this is generally more informative than variation in vegetative parts. Grouping of genera into higher taxonomic levels and classifications such as Family, Order and Phylum were also traditionally based on morphological characters. Then came what Glenny \& Dawson (2008) term "the second Linnaean revolution". Advances in DNA sequencing techniques have made it possible to reconstruct the evolutionary (phylogenetic) relationships of organisms and have revealed that some plants have closer affinities to other families than the ones into which they were previously assigned. The Angiosperm Phylogeny Group (APG), a group of flowering plant taxonomists, is incorporating this DNA evidence into a practical classification system following the ICBN. It is now up to the third update of the classification (APG III 2009).

Major changes affecting both New Zealand weeds and native plant groups can be found in the Scrophulariaceae (the foxglove or snapdragon family). DNA evidence suggests that species and genera formerly included in this family should now be placed in several families, with the foxgloves (Digitalis spp.), snapdragons (Antirrhinum spp.) and Hebel Veronica now belonging in the same family as the plantains (Plantaginaceae), while others such as monkey musk (Mimulus guttatus) now belong 
in the Phrymaceae; only a few of the original scrophs including the type genus Scrophularia (figwort) and the mulleins (Verbascum spp.) are retained. Members of the family Buddlejaceae, which includes the weedy Buddleja spp., have been moved into new circumscription of Scrophulariaceae. As well as rearranging family and higher taxonomic levels, APG has considered that some genera are not significantly distinct to justify their separation from other genera. Hebe being sunk into Veronica is a high profile (at least in New Zealand) example of this (Garnock-Jones et al. 2007), whereas other subgenera are elevated to genus level (e.g. ragwort has been moved from Senecio (S. jacobaea) to the genus Jacobaea (J. vulgaris).

Not all taxonomists accept all proposed changes and the inclusion of Hebe within Veronica is not universally accepted. Another example of different usage of names is provided by comparing the recent major treatments of the world's plants by Heywood et al. (2007) and Mabberley (2008). These authors have different classifications and names for some of the species that are weeds in New Zealand.

\section{NAME CHANGES FOR NEW ZEALAND WEEDS}

The following two tables list most of the name changes applied to New Zealand weeds - changes to genus and species names (Table 1) and changes to families (Table 2) where these differ from the Flora of New Zealand series. Where there are differences of opinion or debate, we have followed Landcare Research (2010) and the name changes used in this paper are also used in the new edition of An illustrated guide to common weeds of New Zealand book (Popay et al. 2010). Of course this is not a final listing of accepted name changes, as these will continue to change as taxonomic research advances.

Table 1 Botanical names for weeds where they have been changed from those in Flora of New Zealand Volumes 3 to 5 (Healy \& Edgar 1980; Webb et al. 1988; Edgar \& Connor 2000).

\begin{tabular}{lll}
\hline Common name & New botanical name & Old botanical name \\
\hline agapanthus & Agapanthus praecox subsp. orientalis & Agapanthus orientalis \\
alpine strawberry & Potentilla vesca & Fragaria vesca \\
aluminium plant & Lamium galeobdolon & Galeobdolon luteum \\
angel's trumpet & Brugmansia $\times$ candida & Brugmansia candida \\
Asiatic and giant knotweed & Fallopia spp. & Reynoutria spp. \\
banana passionfruit & Passiflora tripartita var. mollissima & Passiflora mollissima \\
banana passionfruit & Passiflora tripartita var. azuayensis & Passiflora mixta \\
banana passionfruit & Passiflora tarminiana & Passiflora mixta \\
bomaria & Bomarea multiflora & Bomarea caldasii \\
bulbil watsonia & Watsonia meriana 'Bulbillifera' & Watsonia bulbillifera \\
Bushy asparagus & Asparagus aethiopicus & Asparagus densiflorus \\
Californian mallow & Malva assurgentiflora & Lavatera assurgentiflora \\
Cape pondweed & Aponogeton distachyos ${ }^{2}$ & Aponogeton distachyus \\
Cape tulip & Morea flaccida & Homeria collina \\
catsear & Hypochaeris radicata ${ }^{2}$ & Hypochoeris radicata \\
Cretan mallow & Malva linnaei & Lavatera cretica \\
elephant's ear & Alocasia brisbanensis & Alocasia macrorrhiza \\
fleabane & Conyza sumatrensis & Conyza albida \\
Field hawkweed & Pilosella caespitosa & Hieracium caespitosum \\
German ivy & Delairea odorata & Senecio mikanioides \\
Guinea grass & Megathyrsus maximus & Panicum maximum \\
\hline
\end{tabular}




\begin{tabular}{|c|c|c|}
\hline Common name & New botanical name & Old botanical name \\
\hline ice plant & Carpobrotus chilensis & Carpobrotus aequilaterus \\
\hline Indian strawberry & Potentilla indica & Duchesnea indica \\
\hline introduced cudweeds ${ }^{3}$ & Gamochaeta spp. & Gnaphalium spp. \\
\hline king devil & Pilosella piloselloides subsp. praealta & Hieracium praealtum \\
\hline lake club-rush and & Schoenoplectus spp. & Scirpus spp. \\
\hline $\begin{array}{l}\text { Californian bulrush } \\
\text { monkey apple }\end{array}$ & Syzygium smithii & Acmena smithii \\
\hline Montpellier broom & Genista monspessulana & Teline monspessulana \\
\hline moth plant & Araujia hortorum & Araujia sericifera ${ }^{1}$ \\
\hline mouse-eared hawkweed & Pilosella officinarum & Hieracium pilosella \\
\hline native cudweeds & Euchiton spp. & Gnaphalium spp. \\
\hline nodding spurge & Chamaesyce nutans & Euphorbia nutans \\
\hline nothoscordum & Allium neopolitanum & Nothoscordum inodorum \\
\hline orange hawkweed & $\begin{array}{l}\text { Pilosella aurantiaca and } \\
\text { Pilosella } \times \text { stoloniflora }\end{array}$ & $\begin{array}{l}\text { Hieracium aurantiacum and } \\
\text { Hieracium } \times \text { stoloniflorum }\end{array}$ \\
\hline oxtongue & Helminthotheca echioides & Picris echioides \\
\hline potato vine & Solanum laxum & Solanum jasminoides \\
\hline purple-backed pondweed & Landoltia punctata & Spirodela punctata \\
\hline purua grass & Bolboschoenus spp. & Scirpus spp. \\
\hline ragwort & Jacobaea vulgaris & Senecio jacobaea \\
\hline rambler rose & Rosa $\times$ wichurana & Rosa wichuraiana \\
\hline rice-paper plant & Tetrapanax papyrifer ${ }^{2}$ & Tetrapanax papyriferus \\
\hline sea rush & Juncus kraussii & Juncus maritimus \\
\hline small-flowered nightshade & Solanum nodiflorum & Solanum americanum \\
\hline spotted spurge & Chamaesyce maculata & Euphorbia maculata \\
\hline strawberry & Potentilla $\times$ ananassa & Fragaria $\times$ ananassa \\
\hline strawberry dogwood & Cornus capitata & Dendrobenthamia capitata \\
\hline swamp willow weed & Persicaria decipiens & Polygonum salicifolium \\
\hline tall fescue & Schedonorus arundinaceus & Festuca arundinacea \\
\hline tauhinu & Ozothamnus leptophyllus & Cassinia leptophylla \\
\hline teasel & Dipsacus fullonum & Dipsacus sylvestris \\
\hline tiger lily & Lilium lancifolium & Lilium tigrinum \\
\hline tree mallow & Malva dendromorpha & Lavatera arborea \\
\hline twin cress & Lepidium didymum & Coronopus didymus \\
\hline velvet groundsel & Roldana petasitis & Senecio petasitis \\
\hline wart cress & Lepidium squamatum & Coronopus squamatus \\
\hline water cress & Nasturtium officinale & Rorippa nasturtium-aquaticum \\
\hline water cress & Nasturtium microphyllum & Rorippa microphylla \\
\hline wattles & Acacia spp. & Racosperma spp. \\
\hline willow weed & Persicaria maculosa & Polygonum persicaria \\
\hline willow weeds and & Persicaria spp. & Polygonum spp. \\
\hline $\begin{array}{l}\text { water peppe } \\
\text { wiwi }\end{array}$ & Juncus edgariae & Juncus gregiflorus \\
\hline
\end{tabular}

${ }^{1}$ Misapplication in New Zealand.

${ }^{2}$ Orthographic name change - change to the species spelling to follow the rules of nomenclature.

${ }^{3}$ Marsh cudweed (Gnaphalium uliginosum) is the only species retained in this genus in New Zealand. 
Table 2 Family names for weed species where they have been changed from those in Flora of New Zealand Volumes 3 and 4 (Healy \& Edgar 1980; Webb et al. 1988).

\begin{tabular}{lll}
\hline Species & New family & Old family \\
\hline Acer spp. & Sapindaceae & Aceraceae \\
Agapanthus praecox & Agapanthaceae & Liliaceae \\
Allium spp. & Alliaceae & Liliaceae \\
Araujia hortorum & Apocynaceae & Asclepiadaceae \\
Asparagus spp. & Asparagaceae & Liliaceae \\
Asphodelus fistulosus & Asphodelaceae & Liliaceae \\
Atriplex spp. & Amaranthaceae & Chenopodiaceae \\
Buddleja spp. & Scrophulariaceae & Buddlejaceae \\
Callitriche spp. & Plantaginaceae & Callitrichaceae \\
Chenopodium spp. & Amaranthaceae & Chenopodiaceae \\
Cobaea scandens & Polemoniaceae & Cobaeaceae \\
Cymbalaria muralis & Plantaginaceae & Scrophulariaceae \\
Digitalis purpurea & Plantaginaceae & Scrophulariaceae \\
Fumaria spp. & Papaveraceae & Fumariaceae \\
Hydrocleys nymphoides & Limnocharitaceae & Butomaceae \\
Hydrocotyle spp. & Araliaceae & Apiaceae \\
Hypericum spp. & Hypericaceae & Clusiaceae \\
Landoltia punctata & Araceae & Lemnaceae \\
Lemna minor & Araceae & Lemnaceae \\
Linaria spp. & Plantaginaceae & Scrophulariaceae \\
Mimulus spp. & Phrymaceae & Scrophulariaceae \\
Nephrolepis cordifolia & Lomariopsidaceae & Davalliaceae \\
Paesia scaberula & Dennstaedtiaceae & Pteridaceae \\
Parentucellia viscosa & Orobanchaceae & Scrophulariaceae \\
Pteridium esculentum & Dennstaedtiaceae & Pteridaceae \\
Sambucus nigra & Adoxacea $e^{2}$ & Caprifoliaceae \\
Veronica spp. & Plantaginaceae & Scrophulariaceae \\
Wolffia australiana & Araceae & Lemnaceae \\
\hline 1 &
\end{tabular}

${ }^{1}$ Heywood et al. (2007) retain Chenopodiaceae.

${ }^{2}$ Heywood et al. (2007) list Sambucus as belonging to Sambucaceae.

\section{ACKNOWLEDGMENTS}

We would like to thank the New Zealand Plant Protection Society Incorporated for support in publishing the third edition of "An Illustrated Guide to Common Weeds of New Zealand", from which this paper originated, and to Ines Schönberger, Landcare Research, for prompt replies to our queries.

\section{REFERENCES}

APG III 2009. An update of the Angiosperm Phylogeny Group classification for the orders and families of flowering plants. APG III. Botanical Journal of the Linnaean Society 161: 105-121.

Cockayne L 1929. New combinations in the genus Hebe. Transactions and Proceedings of the New Zealand Institute 60: 465-472.

Edgar E, Connor HE 2000. Flora of New Zealand Volume V. Manaaki Whenua Press, Lincoln, New Zealand. 650 p. 
Garnock-Jones P, Albach D, Briggs BG 2007. Botanical names in Southern Hemisphere Veronica (Plantaginaceae) sect. Detzneria, sect. Hebe and sect. Labiatoides. Taxon 56: 571-582.

Glenny D, Dawson MI 2008. The second Linnaean revolution: DNA sequencing and its impact on traditional taxonomy. New Zealand Garden Journal 11: 10-12.

Healy AJ, Edgar E 1980. Flora of New Zealand. Volume III: Adventive cyperaceous, petalous \& spathaceous monocotyledons. Botany Division, DSIR, Wellington, New Zealand. $220 \mathrm{p}$.

Heywood VH, Brummitt RK, Culham A, Seberg O 2007. Flowering Plant Families of the World. Royal Botanical Gardens, Kew, United Kingdom. 424 p.

International Code of Botanical Nomenclature (ICBN) 2006. (Vienna Code). Regnum Vegetabile 146. A.R.G. Gantner Verlag KG. Available at http://ibot.sav.sk/icbn/main.htm (accessed May 2010).
International Plant Names Index (IPNI) 2010. The International Plant Names Index. http:// www.ipni.org (accessed May 2010).

Landcare Research (2010) Landcare Research Ngā Tipu o Aotearoa - New Zealand Plants databases. http://nzflora.landcareresearch. co.nz/ (accessed May 2010).

Linnaeus C 1753. Species Plantarum. Stockholm, Sweden.

Mabberley DJ 2008. Mabberley's plant book, third edition. Cambridge University Press. $1022 \mathrm{p}$.

Popay AI, Champion PD, James TK 2010. An illustrated guide to common weeds of New Zealand, third edition. Caxton Press, Christchurch, New Zealand. 416 p.

Webb CJ, Sykes WR, Garnock-Jones PJ 1988. Flora of New Zealand Volume IV. Botany Division, DSIR, Christchurch, New Zealand. 1350 p. 